\title{
Love as Attunement
}

\section{Acylene Maria Cabral Ferreira}

Federal University of Bahia, Salvador, Brazil

Email: acylene@ufba.br

How to cite this paper: Ferreira, A. M. C. (2018). Love as Attunement. Open Journal of Philosophy, 8, 85-101. https://doi.org/10.4236/ojpp.2018.82008

Received: December 2, 2017

Accepted: March 4, 2018

Published: March 7, 2018

Copyright $\odot 2018$ by author and Scientific Research Publishing Inc. This work is licensed under the Creative Commons Attribution-NonCommercial International License (CC BY-NC 4.0). http://creativecommons.org/licenses/by-nc/4.0/ (c) (i) \& Open Access

\begin{abstract}
We aim to show, using Being and Time and Zollikon Seminars, that solicitude (Fürsorge) as the disclosedness of being-with is the condition of possibility for the existential-ontological constitution of the attunement of love. Centered on the text On the Essence of Truth, our purpose is to emphasize that freedom is also an attunement. Our hypothesis is that the copertinence of love (the fundamental disclosedness to the other) and of freedom (the letting-be of the other) consists in a modification of the existential of disposedness (Befindlichkeit) and expresses the unity and ontological circularity of being-in-the-world.
\end{abstract}

\section{Keywords}

Love, Attunement, Disclosedness, Disposedness, Freedom, Being-With

\section{Introduction}

Heidegger has been criticized for his silence in relation to the topic of love. In Being and Time, his best known work, we encounter only a single reference to love, in a note containing citations from Pascal and Saint Augustine (Heidegger, 2010: p. 135). In addition to this work, we have some discussion of love in Nietzsche I and in the Zollikon Seminars. "Thanks to the publication of Heidegger's last Marburg lectures from the summer semester of 1928, we know that the reference to this fundamental role of love originated in conversations with Max Scheler on the problem of intentionality." (Agamben, 2008: p. 90). Nevertheless, the paucity of the references to the theme of love should not be taken to mean that Heidegger disregarded its importance for philosophy. In our view, we find justification for exploring further Heidegger's regard for the question of love. We should emphasize that, earlier, in 1987, Agamben held a conference in Paris called La passion de la facticité, at which he affirmed that love is the passion of facticity of Dasein, by means of which Dasein experiences freedom as impoten- 
tiality (Agamben, 2008: p. 105). For us, love more appropriately concerns the structure being-in-the-world, seeing that this structural modality presupposes the disclosedness of Dasein to those other entities that share the world with it. From the view of Françoise Dastur, "being grounded ourselves in the existential analytic and not seeking the 'whole-there,' that we are able to elaborate a 'phenomenology of love." (Dastur, 2008: p. 119). We can add, in agreement with Dastur and Agamben, that the themes of love and freedom are subtended to the existentials that structure and constitute the disclosedness of Dasein in its relation with being and with entities. Considering that love and freedom are grounded in the existential structures of Dasein we are able, first of all, to affirm that freedom and love are existential-ontological disclosednesses of being-in-the-world. This declaration of ours that may seem at first to be precipitous and frivolous, is supported in a passage from the Zollikon Seminars, according to which love is grounded in the understanding of being (Heidegger, 2001: p. 190). As a result, we can say that love for Heidegger is grounded in an existential. What is the theoretic fundamental that grounds such an inference? The existentiality of Dasein, that consists in the co-pertinence of existentials and in their equally originary disclosednesses, determines each instance and genuinely the modes of being of Dasein. In accordance with Being and Time (paragraph 31), the existential of understanding is tuned with the existential of disposedness [Befindlichkeit] ${ }^{1}$ and disposedness always includes the understanding of being. (Heidegger, 2010: p. 138). These specific theoretic references that we take from the Zollikon Seminars and from Being and Time permit us to correlate love to the existential of disposedness and, consequently, to define it as an attunement [Stimmung], ${ }^{2}$ this is "ontically what is most familiar and an everyday kind of thing: mood, being in a mood" (Heidegger, 2010: p. 130).

In the conference cited above, Giorgio Agamben asserts that love is the absent Stimmung from Being and Time. This assertion is of utmost importance and decisive for our consideration of love in Heidegger because it supports and permits us to defend the thesis that love is a mode of attunement. "If Heidegger," Agamben says, "therefore does not thematically treat the problem of love, although recognizing its fundamental status, it is precisely because the mode of Being of an opening that is more original than all, knowledge (and that takes place, according to Scheler and Augustine, in love) is, in a certain sense, the central

\footnotetext{
${ }^{1}$ JohnMacquarrie and Edward Robinson (Heidegger, 2008) translate Befindlichkeit as "state-of-mind". Joan Stambaugh (Heidegger, 2010) translates it as "attunement". We translate it as "disposedness" following Daniel O. Dahlstrom (2013: p. 62).

${ }^{2}$ Joan Stambaughas well as John Macquarrie and Edward Robinson translate Stimmung as "mood". We translate it as "attunement", following William McNeill and Nicholas Walker (Heidegger, 1995: p. 67). "Attunements are ways of being-there of Da-sein, and thus ways of being-away. An attunement is a way, not merely a form or a mode, but a way [Weise] —in the sense of a melody that does not merely hover over the so-called proper being at hand of man, but that sets the tone for such being, i.e., attunes and determines the manner and way [Art und Wie] of his being. [...] Attunement is a fundamental manner, the fundamental way in which Dasein is as Dasein. [...] Attunements are the fundamental ways in which we find ourselves disposed in such and a such way. Attunements are the "how' [ Wie] according to which one is in such and a such way."
} 
problem of Being and Time." (Agamben, 2008: p. 91). The most originary disclosedness to which Agamben refers is to the structure being-in-the-world, because this grounds Dasein as being that is already encountered disclosed and thrown in the world. This characteristic of Dasein Heidegger denominates as facticity: "The factuality of the fact of Dasein, as the way in which every Dasein actually is, we call its facticity." (Heidegger, 2010: p. 56). It is well to emphasize that the facticity of Dasein discloses the double character of factuality: of what Dasein is, and of what it may be as thrownness in the world in whatever mode of being. This double character of facticity is the condition of possibility that constitutes the character of the disclosedness of Dasein. As facticity, the structure being-in-the-world is the most originary disclosedness of Dasein, and for this reason this structure will be the base for our reflection on love and freedom in Heidegger.

Despite our agreement with Agamben that love and freedom are co-pertinences in the Heideggerian philosophy, we follow a line of exposition of the theme significantly different from that which he presented in "The Passion of Facticity", especially with reference to love as the passion of facticity (Agamben, 2008: p. 107), and to freedom as an experience of impotentiality. The fact that we will consider love as an attunement instead of as a passion necessitates an elaboration of the concept of love different from that of Agamben. Why? As the passion of facticity, love is grounded in the existential of falling [Verfallen], while as attunement it is grounded in the existential of disposedness. This is because in Being and Time facticity is the character of the existential of falling, and attunement is a modification of the existential of disposedness. Why do we relocate the grounding of love to the existential of disposedness? Simply because any modality of love involves a tuning or an attunement of Dasein with Dasein-with [Mitdasein]. ${ }^{3}$ As a consequence of this relocation, facticity ceases to be the pillar that supports and structures the concept of love in Heidegger. Thus in place of our relating facticity to notions of radical impotentiality (Agamben, 2008: pp. 104-105), irreducible inauthenticity of beings (Agamben, 2008: p. 107), eternal beyond being (Agamben, 2008: p. 107), we understand that facticity is the ground for the unconcealment of the authentic mode of the being of Dasein.

How is this so? In falling, factical Dasein is in the mode of being of inauthenticity or, better, it unconceals itself in the mode of being of others. Because of this, the dissimulation of itself in others is the mode of the unconcealment of Dasein. This denotes that the authentic mode of the being of Dasein is encountered latent in its inauthentic mode of being. This is to say, the concealed and the unconcealed constitute a latent doubleness in the existential of falling. This doubleness is the condition of possibility that permits factical Dasein to dissuade itself from latency and to unconceal itself authentically. Because falling, existentially, is expressed as facticity, we can add that the doubleness, con-

${ }^{3}$ Joan Stambaugh, John Macquarrie and Edward Robinson translate Mitdasein as Dasein-with, and Daniel Dahlstrom as "being-here-with". We translate it as "Dasein-with". When Dasein is encountered by another Dasein in the world, it is designated Dasein-with (Heidegger, 2010: p. 116). 
cealed/unconcealed, is expressed in facticity as the doubleness, authenticity/inauthenticity. What is the function of these pairs of doubleness? They permit us to infer that facticity, by means of its character of inauthenticity, is the condition of possibility for the unconcealment of the authentic mode of the being of Dasein. Although facticity is characterized by inauthenticity, we do not think, as does Agamben, that it is eternal and beyond being, seeing that now and again factical Dasein becomes authentic. For Agamben, the dynamism and reciprocity between authenticity and inauthenticity has its end in love, because "lovers bear the impropriety [inauthenticity] of love to the end so that the proper [authentic] can emerge as the appropriation of the free incapacity that passion brings to its end." (Agamben, 2008: p. 107). Now if from this appropriation of impotentiality emerges the authentic, then will not love be the appropriation of the authentic within inauthenticity? Is this not the same as saying that love concerns the authentic? As a consequence, when we think of love as an impotentiality of freedom that maintains us in an irreducible inauthenticity, we reflect on the means by which love is a disclosedness that frees Dasein and Dasein-with for their authentic mode of being. From this perspective, we argue that the co-pertinence of love and freedom consists in the attunement of freedom (i.e., letting-be the entity) grounds the attunement of love as the fundamental attunement for the being-with-one-another of Dasein in the mode of everydayness.

In Being and Time, angst is defined as fundamental disposedness, while in Fundamental Concepts of Metaphysics. world, finitude, solitude, profound boredom is seen as the fundamental attunement necessary to philosophizing. For Heidegger, "every genuine fundamental attunement liberates and deepens, binds and releases the others...Consequently it is just as mistaken to ascribe an absolute status to one fundamental attunement alone as it is to relativize all the possible fundamental attunements with respect to one other." (Heidegger, 1995: p. 182). This citation confirms for us the fact that profound boredom is not the only fundamental attunement under which all the others are to be subsumed. As Heidegger's words accentuate, there is a co-pertinence and co-originariness among fundamental attunements. This construction enables and authorizes us to locate love as the fundamental attunement for the being-with-one-another of Dasein.

Meanwhile, it is opportune to ask ourselves: how will it be possible to treat the theme of love with consistency and legitimacy, seeing that Heidegger almost never considers it? We intend to confront the challenge of advancing our reflections on love in Heideggerian thought by means of analyzing the concepts of being-with and solicitude (Fürsorge) ${ }^{4}$ described in Being and Time and the concept of freedom as attunement and the letting-be of entity described in the text

${ }^{4}$ Joan Stambaugh translates Fürsorge as "concern" (Heidegger, 2010: p. 118). We translate it as "solicitude", following the translation of John Macquarrie and Edward Robinson. "Indeed the word 'Fürsorge' is regularly used in contexts where we would speak of 'welfare work' or 'social welfare'; this is the usage which Heidegger has in mind in his discussion of 'Fürsorge' as 'a factical social arrangement."' (Heidegger, 2008: p. 157, note 4). 
On the Essence of Truth. Our hypothesis in this theoretic procedure gets support from this statement of Günter Figal: "we can develop the central thought of the Heideggerian philosophy and carry it yet further, by returning to the descriptive richness of Being and Time." (Figal, 1988: p. 22). In addition, in order for us to show that the co-pertinence of love as the disclosedness to the other, and of freedom as the letting-be of the other, constitutes the fundamental attunement for the being-with-one-another of Dasein, we transcribe for support the citation from Zollikon Seminars that sends us to the instrumental theoretic of Being and Time: "But correctly understood (i.e., in a fundamental-ontological sense) care is never distinguishable from 'love' but is the name for the ecstatic-temporal constitution of the fundamental characteristic of Da-sein, that is, the understanding of being." (Heidegger, 2001: p. 190). In keeping with Heideggerian philosophy, we can add that the existential-ontological constitution between love, care, and the understanding of being is concentrated in the disclosedness of Dasein to being and to the other; that is, it concerns the most originary disclosedness to Dasein: being-in-the-world. For this reason, the co-pertinence of the disclosedness of being-in-the-world will constitute the drive shaft for our thinking through this question of love and freedom in Heidegger.

In his studies of amor fati and the will to power as affect, passion, and feeling, Heidegger recovers Nietzsche's thought that "all affects are 'configurations' of will to power. If we ask what will to power is, Nietzsche answers that it is the original affect. Affects are forms of will; will is affect." (Heidegger, 1991: p. 44). In spite of the themes of passion, of will, of wanting and of desire that are common to discussions of love, we will not deal with these here, because in Being and Time the ontological possibility of desire is correlated to the constitutive moments of care and "wishing presupposes care." (Heidegger, 2010: p. 188). Therefore, wanting and desire are phenomena of Dasein, while care and love, in our view, are phenomena of Dasein considered as disposedness. Methodologically, the structural moments and constituents of Dasein in the existential analytic are treated separately, but existentially and factually these express the unity and ontological circularity of being-in-the-world. In the existential analytic, the phenomenon of care corresponds to the unity and totality of the structural whole of Dasein; consequently disposedness, being-with, and attunement of love concern care. So, from the ontological point of view wanting, desire, love, disposedness, being-in-the-world, being-with, care, etc. are treated as distinct forms, but existentially they correspond to the unity of the modes of being of Dasein. From this ontical point of view wanting, love, and desire are also thought of under different perspectives, but factically they are found intimately intertwined and they express the profusion and the correspondence of the modes of being of everyday Dasein. Because in our understanding ontological circularity grounds the constitution of the structure being-in-the world and of the instances of disclosedness of Dasein, we consider that it is the necessary condition of the possibility for our reflecting on love and freedom in Heidegger. Our pur- 
pose is to show that the ontological nexus of the doubleness of facticity, i.e., being-with/solicitude, and of the doubleness of attunement of love, i.e., solitude/freedom, reflect the ontological circularity that structures the totality and the unity of the different modes of being of Dasein in its everydayness.

\section{The Ontological Circularity of "Being-With" and Love as Attunement}

According to Heidegger "the 'doctrine' of a thinker is that which remains, within what is said, unsaid, that to which we are exposed so that we might expend ourselves on it. In order to experience and to know for the future what a thinker left unsaid, whatever that might be, we have to consider what he said." (Heidegger, 1998: p. 155). In this way, if we wish to understand the not said in the thinking of Heidegger about love as the absent Stimmung, we have to resort to the concepts that he has elaborated. As we earlier stated, it will be impossible for us to treat of attunement of love without first explaining how the structure of being-in-the-world is constituted, since it is the fundamental existential-ontological of Dasein in its relation with the world. In what sense does this structure help us to reflect on love in Heideggerian thought? Why is it that through this we are able to think of love as attunement? Why is its disclosedness essential for the attunement of love? How is it to be constituted?

The structure being-in-the-world is constituted by the unity of the existentials of being-in, being-alongside, and being-with. These existentials are equally primaries and originaries but indivisibles, all three of which concern the determination of Dasein as being-in-the-world. While as being-in, Dasein is, and is thrown in the world; while as being-alongside, it touches and is touched by the world; and while as being-with, it is in a relation of solicitude with the other Dasein. As existentials, each one of them presents a specific character of disclosedness with equal originariness and inseparability. Thus as the existential of disposedness, it is grounded in the existential of understanding, and reciprocally; the existential of being-alongside is grounded in the existential of being-in; and the existential of being-with is grounded in the existential of being-in and being-alongside, and reciprocally. With methodological recourse, we will indicate separately the disclosedness pertinent to the existentials that structure Dasein while being-in-the-world: 1) "This prior disclosedness of the world which belongs to being-in is also constituted by attunement." (Heidegger, 2010: p 133). 2) The disclosedness of being-alongside is in accord with the disclosedness of the significance of the worldliness of the world. 3) Now the disclosedness that concerns the existential of being-with is the disclosedness to the other, solicitude. Given the existential-ontological constitution of the structure being-in-the-world, we ask: what is the grounding of this most originary structure of Dasein? As Jean Greisch says, "disposedness is the condition of possibility of directing-itself-toward (Sichrichten auf). [Therefore] where there is no disposedness there can be neither being-in-the-world nor being-with-the-other." (Greisch, 
1994: p. 182). To the degree in which the existential of disposedness is the condition of possibility by which Dasein directs itself toward the world and thus to the other, we can say that disposedness is the grounding of the structure being-in-the-world, and, consequently, of the existential of being-with. We can add further that disposedness is the grounding of all and whatever that relates Dasein with the world, that is, it is the source of all moods, affections, emotions, etc. In this manner it is the existential-ontological grounding of all attunements. But how does disposedness constitute being-with? From our point of view, disposedness grounds being-with as the attunement of love. Why? Because it is characterized by solicitude.

In the same way that attunement is the mode by which ontically we know disposedness, we understand that solicitude is the mode by which ontically we know being-with. Considering that love is a mode of the attunement of Dasein with an other Dasein, and that the solicitude of being-with characterizes the relation of disclosedness between one Dasein and an other, we have conditions for affirming that solicitude is indispensible for the existential-ontological constitution of the attunement of love, because the affect of love is unthinkable without the disclosedness of Dasein to an other Dasein. In this perspective, solicitude will be our support for reflecting on the attunement and disclosedness of love.

But the characteristic of encountering others is, after all, oriented toward one's own Dasein... "Others" does not mean everybody else but me-those from whom the I distinguishes itself. Others are, rather, those from whom one mostly does not distinguish oneself, those among whom one also is (Heidegger, 2010: p. 115).

Said in another way, Dasein is the other of itself. This means that Dasein understands its own authentic being, to the degree that it understands also the being of the other Dasein and reciprocally. In this sense, we can indicate a doubleness in the existential of being-with that concerns the understanding of being of Dasein: it understands itself by means of understanding the other, and it understands the other by means of understanding itself. We have here an ontological circularity, from which we have no escape, given that the existential structure of Dasein as well as the understanding of being as given in Being and Time happen in a circularity. Dasein, "beings which, as being-in-the-world, are concerned about their being itself have an ontological structure of the circle." (Heidegger, 2010: p. 148). For this reason Dasein understands being, itself, and the other in an ontological circularity. In the circularity of being-with, Dasein understands itself as an entity that itself is; better, it recognizes itself as a self that is being-with-one-another at the same time in which it recognizes the other also as a self that is being-with-one-another and for whom it is the other. Dasein "can recognize others like himself in the world and enter into relations with them because his own being is disclosed to him as being-with.” (King, 2001: p. 75). In this way, we are able to say that the term "with" corresponds to the character of 
disclosedness of Dasein as the understanding of the being of the other and of its being-with-one-another.

In Being and Time, when Dasein frees its being in the direction of others, Dasein is designated by the term "Dasein-with"; and the other Daseins that are being-with-one-another and take part in the world with Dasein and Dasein-with are denominated as "are there." (Heidegger, 2010: p. 123). Dasein frees its being in the direction of Dasein-with because it is structured by the disclosedness to the other that characterizes the existential of being-with. As far as it is structured by being-with, Dasein is disclosed as being-with-one-another to Dasein-with, that is, it is directed to the encounter with the other Dasein. We need to remember that Dasein-with, in its turn, is also Dasein that frees its being in the direction of the other Dasein (Dasein-with). The simultaneity and reciprocity of disclosedness and of the freedom of being between Dasein and Dasein-with is evidence of yet another doubleness in the existential of being-with: the freedom of the being of Dasein in the direction of Dasein-with and its reciprocal. From there we can affirm that the character of disclosedness of being-with determines another doubleness related to the ontological circularity of being-with, which is to say, the understanding of the other's being and the freedom of being in the direction of the other. Although distinct, the characters of these pairs of doubleness are inseparable and they constitute, by way of co-pertinence, the unity of the ontological circularity of being-with. To develop the thought more clearly, the disclosedness of being-with precedes and grounds the understanding and the freedom of being for the other. In this way, the understanding and freedom of being for the other are co-originaries and co-pertinences to the unity of the disclosedness of the ontological circularity of being-with. What is the contribution of the ontological circularity of being-with to our reflection on love as attunement? It grounds and demarcates the everyday being-with-one-another of Dasein, without which we are unable to speak of the disclosedness and attunement of love. Being-with-one-another, originary to the ontological circularity of being-with, grounds the coexistence of Dasein, in which Dasein is being-with-for-the-other as well as for the sake of the other. Why is it that in coexistence being-with is able to understand and free being for the other? Because being-with is solicitude, the disclosedness that precedes the understanding and grounds the freedom of being for the other. What allows us to correlate being-with to the attunement of love? The fact that "it is in attunement that Dasein discovers itself freed and exposed to being." (Greisch, 1994: p. 180). It is in being-with that Dasein discloses itself to the other, but it is in the attunement of love that Dasein is able to effect the encounter with another Dasein through the understanding and freedom of being for the other.

Thus being-with is the existential that structures Dasein as disclosedness to the other, and love is the disclosedness of Dasein to the encounter, the coexistence, with the other. In this way, love is attunement, an existential modification of disposedness that characterizes Dasein in its relation to Dasein-with. In this sense, 
love is the fundamental attunement for the everyday being-with-one-another of Dasein.

\section{The Solicitude of Being-With and the Disclosedness of the Attunement of Love}

"The disclosedness of the Dasein-with of others which belongs to being-with means that the understanding of others already lies in the understanding of being of Dasein because its being is being-with." (Heidegger, 2010: p. 120). From this quotation in Being and Time and that in the Zollikon Seminars (Heidegger, 2001: p. 190) we intend to correlate the disclosedness of being-with to the disclosedness of the attunement of love; because the first affirms that the disclosedness of Dasein-with involves the copertinence between the understanding of itself and the understanding of the other, and the second affirms that love, by its similarity to care, copertains to the understanding of being. These citations permit us to infer that in the attunement of love Dasein situates itself for the sake of the other and understands itself from the understanding of the being of Dasein-with. With such inference we are not juxtaposing, reducing, or transforming the disclosedness of being-with in the disclosedness of the attunement of love. In this way, our objective is to demonstrate that, from the existential of being-with, it is possible that we may ground the mode of the attunement of love and deepen our studies of Heideggerian philosophy. In conformity with our earlier point of view that solicitude, the disclosedness of being-with, is the condition of possibility for the existential-ontological constitution of the attunement of love, since it is well-known that this attunement requires the disclosedness to the other to be grounded. How is the solicitude of Dasein constituted?

Earlier, we affirmed that being-with presents an ontological circularity evidenced by the character of doubleness in reference to the understanding and the freedom of being to the other. If being-with is the existential-ontological ground of solicitude, consequently that also constitutes a character of doubleness, that is, the doubleness of authentic solicitude and inauthentic solicitude. However, starting with the presupposition that the disclosedness of being-with, solicitude, grounds the disclosedness of the attunement of love, we should equally presuppose that the doubleness of solicitude grounds a doubleness in the attunement of love. What may be the character of this doubleness? How does the doubleness of being-with and of solicitude interact with the attunement of love? What does this doubleness signify for the constitution of Dasein as being-in-the-world?

In Ontologie et temporalité, Greisch gives the following explanation:

The being-with is expressed through solicitude. This fundamental existential structure permits a great number of variations, as many positive as negative ones. Under the negative version, there are numerous forms of indifference, of "non-assistance to persons in danger," that make part of the effective functioning of society. Under the positive version Heidegger mentions two fundamental modalities: in the first instance, I substitute myself 
for the other in order to procure for it that which it cannot procure for itself.... Next to this first possibility (relieving the other of its "cares" by taking them to itself) Heidegger sees another possibility that directly concerns the existence of the other. It consists in making the other sufficiently free and autonomous so that it can assume its cares itself (Greisch, 1994: p. 162-163).

From this explanation, we can say that the solicitude is inauthentic when Dasein puts itself in the place of the other, substituting it in "care" with itself, and when Dasein discloses to the other the possibility of the other's taking care of itself by itself we can say that the solicitude is authentic. We can go beyond this description from Being and Time and add that authentic and inauthentic solicitude ground the doubleness of the attunement of love as disclosedness and closedness.

What difference can we establish between the pairs authentic/inauthentic and disclosedness/closedness? The difference consists in this: that the first pair refers to the modes of being of Dasein and the second to the character of the existentials. For example: solicitude, as disclosedness, is a character of the existential of being-with. But solicitude is authentic when it expresses being-with in a mode genuine and free, and it is inauthentic when it expresses being-with in a mode leveling and dominating. In the positive version of solicitude, the being-with-one-another of Dasein is governed by authentic and inauthentic solicitude. On the other side, we are able to speak of the disclosedness and closedness of the attunement of love by referring ourselves to the characters that ontologically constitute this attunement of the existential of disposedness because as a modality of this existential, the attunement of love retains the same characters. Then only from the character of disclosedness or closedness can we speak of modes of being of the attunement of love. This means that the character of disclosedness or of closedness determines modes of authentic or inauthentic being. What is the relevance of the doubleness of being-with and of solicitude for the constitution of the attunement of love?

The doubleness of being-with, characterized by the ontological circularity of understanding and of the freedom of being for the other, and the doubleness of authentic and inauthentic solicitude grounds the doubleness of the attunement of love (disclosedness and closedness), to the degree in which they converge in the attunement of love to understanding, freedom, and solicitude with the other. From this convergence it is possible to assert that in the attunement of love Dasein can disclose itself to the other and understand itself to itself, assuming its own authentic potentiality-for-being at the same time that it frees the other to understand itself, freeing itself to assume the responsibility of being itself. In the character of the disclosedness of attunement of love, Dasein and Dasein-with are free to be and to assume what they have as being.

On the other hand, from the convergence of these pairs of doubleness it is also possible to affirm that in the attunement of love Dasein can close itself to the 
other, obscuring to itself and to the other the understanding and freedom of being that concerns each. In this obscuring of understanding and of freedom of being Dasein as well as Dasein-with are exempted from the responsibility of taking up their potentiality-for-being. In conformity with the Heideggerian thought in Being and Time and beyond it (Heidegger, 2001: p. 190), we will say that the character of the disclosedness of the attunement of love grounds the authentic mode of being of love, whereas the character of closedness grounds the inauthentic mode of being of love.

In inauthentic solicitude, Dasein locates itself in the place of the other in order to take care of that which concerns the other, discharging and disencumbering the other of taking on the care even of itself, substituting for it, therefore, in this care; and in the closedness of the attunement of love, Dasein understands through the mode of being that is not its own, identifying itself with it and closing itself to its authentic possibilities of being. What is the difference between the mode of inauthentic solicitude and this of the closedness of attunement of love? The difference resides in the fact that with inauthentic solicitude Dasein located itself in care with the other, while in closedness of attunement of love Dasein takes on as its own the understanding of being that the other has of it, putting aside and losing its own self. In spite of this difference that we point out, we can say inauthentic solicitude and the closedness of attunement of love lead to the same place: namely, to the reserve of freedom of being. In this way the copertinence and co-originariness of inauthentic solicitude and of the closedness of attunement of love in the ontological circularity of being-with become evident. This evidence clarifies further that inauthentic solicitude and the closedness of attunement of love level the mode of being of Dasein-with to that of Dasein. At the same time, in authentic solicitude Dasein frees the other to care for its own self, to be autonomous and free. Already in the disclosedness of the attunement of love, Dasein frees the other to assume its authentic being, turning transparent to itself and to Dasein-with, at the same time that it leaves Dasein-with to be that which it is as being. With this, Dasein frees Dasein-with to its potentiality-for-being, to understand itself to itself and, reciprocally, to be understood as being free and transparent to its authentic potentiality-for-being. Authentic solicitude and the disclosedness of attunement of love copertain and are co-originary in the ontological circularity of being-with, that is, in the understanding and the freedom of being of Dasein and of Dasein-with.

\section{The Being-Alone of Being-With and the Attunement of Solitude}

"Being-with existentially determines Dasein even when an other is not factically present and perceived. The being-alone of Dasein, too, is being-with in the world. The other can be lacking only in and for a being-with. Being-alone is a deficient mode of being-with; its possibility is a proof for the latter." (Heidegger, 2010: p. 117). But in what sense can Dasein be being-alone, if existentially it is 
being-in, being-alongside to the world, and being-with to Dasein-with? Is it because being-alone is a deficient mode of being-with? Which attunement corresponds to this mode of being of Dasein? What is the relationship between being-alone and the attunement of love? The deficiency of being-alone does not refer to a negative attribute of the existential structure of being-in-the-world; on the contrary, being-alone exposes the lack of Dasein-with to being-in-the-world. This revelatory lack, instead of hiding or weakening being-with, unmasks and strengthens it, showing then that if in fact Dasein-with can be lacking to being-in-the-world, it is "because Dasein as being-with lets the Dasein of others be encountered in its world.” (Heidegger, 2010: p. 117).

We can say that when Dasein feels itself alone it is solitary; and for this reason we are able to refer the term "solitude" to the being-alone of being-with. However, solitude is not a deficient mode of Dasein, rather it is an attunement of Dasein with the other in the mode of being-alone. But if being-alone is a deficient mode of being-with why do we deny that solitude may be a deficient mode of Dasein? Because being-alone, on one side, is a mode of being-with and, on the other side, it is a character of attunement that displays Dasein in the mode of being by itself. We make this affirmation supported by the fact that in the existential analytic Dasein is always in attunement, meaning that it is always in tune with a situation "for the most part in terms of the surrounding world taken care of that is shared [Mitwelt]." (Heidegger, 2010: p. 122). This consideration implies that Dasein, while structured by the deficient mode of being-with, is in attunement of solitude. In this way, we can therefore affirm that the existential of being-with grounds the attunement of solitude. However, we earlier affirmed that the existential of being-with grounds the attunement of love. Was there a latent contradiction in these assertions? No, our intention with such inferences is to show that the existential of being-with, through the mode of being of being-there-with, grounds the attunement of love, and through the mode of being of being-alone, grounds the attunement of solitude. In accord with what we already indicated, being-with is characterized by a structural ontological circularity that characterizes the doubleness of solicitude and the attunement of love. Now, if solitude, like love, is an attunement founded on being-with, then it too will be characterized by a doubleness. How is the doubleness of solitude constituted? We saw that one of the pairs of this doubleness is the being-alone that marks the absence of Dasein-with. What will the other half of the pair be? The being-alone that singularizes Dasein. "What is this solitude, where each human being will be as though unique? What is that-individuation [Vereinzelung]?" (Heidegger, 1995: p. 6).

The doubleness that characterizes solitude consists, on one hand, in the fact that Dasein feels itself alone and abandoned by Dasein-with, finding itself in a situation of withdrawal from itself and, on the other hand, in the fact that Dasein feels itself abandoned to itself, finding itself in a situation of proximity with its own self. The difference in these modes of being-alone, characteristics of the at- 
tunement of solitude, is that, in the first case, the other becomes Dasein in the mode of absence, which is to say, the absence of Dasein-with determines the mode of the being of Dasein as loss and emptiness of itself. This mode of the attunement of solitude relates to the abandonment and dispersal of the being of Dasein to the other. Then, while as attunement, solitude is grounded in the existential of disposedness and this "is itself the existential kind of being in which it is continually surrendered to the 'world' and lets itself be concerned by it in such a way that it, in a certain sense, evades its very self." (Heidegger, 2010: p. 135). In the second case, the other mode of being-alone of solitude unmasks Dasein to its own individuation. In the mode of absence, Dasein counts on Dasein-with to fill up its emptiness of being; in this mode Dasein trusts that Dasein-with is able to make a decision about potentiality-for-being that it itself has of being, just as Dasein is dispersed in the waiting for decision of Dasein-with, detaching itself from itself. Now in the mode of individuation, Dasein refuses to concern itself in the absence of the other and in the expectation of decision of Dasein-with, and assumes its own potentiality-for-being, becoming singular and unique. In this instance we have "an ultimate solitariness of man, in which everyone stands for him- or herself as someone unique in the face of the whole." (Heidegger, 1995: p. 8). Therefore solitude, in the mode of individuation, instead of exhibiting the loss and distancing of Dasein from itself, concerns the proximity and conquest of potentiality-for-being that it itself is. In this sense, solitude singularizes Dasein because it makes possible its transparency to itself to realize an authentic mode of being that it characterizes as unique before Dasein-with in the shared world. How can we correlate the attunement of solitude to the attunement of love? They are copertenences and co-originaries in the ontological circularity of being-with, in which Dasein understands and frees being for the other. "Being toward others is not only an autonomous, irreducible relation of being, as being-with it already exists with the being of Dasein." (Heidegger, 2010: p. 121). That is to say, the character of disclosedness to the other that expresses the being-with as solicitude grounds the attunement of solitude and the attunement of love. The copertinence and co-originarity of solicitude, attunement of solitude, and attunement of love are constituted in the ontological circularity of being-with.

\section{Conclusion: The Resonance of the Attunements of Love and of Freedom}

In Nietzsche I, Heidegger affirms that ' $[A]$ mor-love-is to be understood as will, the will that wants whatever it loves to be what it is in its essence." (Heidegger, 1991: p. 207). We saw, earlier, that for Nietzsche will is affect, so that the phrase, "love is to be understood as will," may be read in the following way: love is to be understood as affect. In Being and Time, affect is an attunement. Then, if we say that love is affect, at once it is attunement: a modification of the existential of disposedness. This reasoning confirms the principal thesis of our reflec- 
tion, that is, love is a fundamental attunement for the being-with-one-another of Dasein. As love is an attunement, it is also a "comportment", that is, an encounter of the disclosedness of Dasein with the disclosedness of Dasein-with, an encounter together and open, seeing that "in disposedness, the comportment each time meets a beginning." (Figal, 1988: p. 166). The reciprocal disclosedness of Dasein and of Dasein-with is the necessary and originary condition for comportment, for the meeting and the return of being-in-the-world to its possibilities of being. In the disposedness, the return and the beginning constitute the inaugural moment and foundation of the modes of being of Dasein.

"This possibility-of-the-return-to-the-beginning may denominate, simply, freedom." (Safranski, 2006: p. 30). Understood as letting-be the other that which it is, freedom is the foundation for the unconcealment of the authentic mode of being of Dasein. In On the Essence of Truth, freedom while letting-be the other is considered an attunement or being attuned that "can be 'experienced' and 'felt' only because the 'human being who experiences', without being aware of the essence of the attunement, is always engaged in being attuned in a way that discloses being as a whole." (Heidegger, 1998: p. 147). Parallel to Heidegger's interpretation of amor fati, we can say that in attunement of love Dasein frees being for the other, that is, it lets Dasein-with be that which it is. Thus the attunement of love and the attunement of freedom are equally copertinent and co-originary to the disclosed comportment of Dasein. Therefore, "every open relatedness is a comportment...Freedom for what is opened up in an open region lets beings be the beings they are. [In this way,] freedom is engagement in the disclosure of beings as such." (Heidegger, 1998: pp. 141-145). To the degree in which in the attunement of love Dasein and Dasein-with may be what they are, we can say that the attunement of love is copertinent with the attunement of freedom. Because the attunement of freedom articulates disclosedness to the being of Dasein and of Dasein-with and lets them be the entities that they are, we can say that the attunement of freedom is the condition of possibility for the attunement of love. This signifies that the attunement of freedom precedes and suffuses the attunement of love. Better: the articulation of the disclosedness to being of Dasein and Dasein-with in the attunement of freedom enables the meeting, the comportment, of the disclosedness of the understanding and freedom of being for the other in the attunement of love. Such articulation makes evident that in the attunement of love "freedom is the highest necessity." (Heidegger, 1951: p. 42). Owing to the articulation between disclosedness to being of Dasein and Dasein-with and the disclosedness to understanding and freedom of being for the other that let Dasein and Dasein-with assume the potentiality-of-being that they have for being, we think that the attunement of love is grounded on the attunement of freedom as letting-be, and that attunement of freedom resounds in attunement of love. We understand in this way because in the authentic mode of attunement of love, Dasein lets Dasein-with be that which it is of being, freeing itself and Dasein-with to individuation, and reciprocally. 
In this way, we show the co-originarity and the copertinence between the attunement of freedom and the attunement of love.

The being-with-one-another of those who are employed for the same thing often thrives only on mistrust. On the other hand, when they devote themselves to the same thing in common, their doing so is determined by the Dasein that each has grasped as his own. This authentic alliance first makes possible the proper kind of objectivity [Sachlichkeit], which frees the other for himself in his freedom (Heidegger, 2010: p. 119).

The mode of distrust that often rules the reciprocal being-with-one-another of Dasein expresses the character of the concealment of the attunement of freedom and, at the same time, the character of the concealment of the attunement of love. These characters constrain Dasein into inauthentic modes of being. From the concealment of Dasein to the receptivity of Dasein-with's disclosedness of being and the refusal of Dasein to let Dasein-with be its own self, we have the inauthentic mode of the attunement of freedom. And from the concealment of Dasein to the receptivity of disclosedness to, and understanding of, the other or in the refusal of Dasein to free being for the other, letting Dasein-with assume the being that it itself is, we have the inauthentic mode of the attunement of love. Similarly, the attunement of love and the attunement of freedom, in the characters of concealment and in the inauthentic modes of these attunements, are co-originaries and copertinences.

We can add further that in the inauthentic mode of attunement of love it seems that Dasein takes Dasein-with as if it were present-at-hand, even though "the being of the authentic self can be understood still less as objective presence." (Heidegger, 2010: p. 126). In inauthenticity, Dasein unburdens Dasein-with of being that which it is (inauthentic solicitude) at the same time that it determines the mode of being that it should assume as itself (inauthentic attunement of love). To this degree we say that there is an encounter of the character of concealment of Dasein and of Dasein-with for the authentic possibilities of being of each of them. Because of this we affirm that in the inauthentic attunement of love there is an inauthentic attunement of freedom, seeing that in the inauthentic attunement of love Dasein-with coexists with the concealment of Dasein to the freedom of the possibility-of-being that is authentic to it. Therefore, in the concealment and inauthenticity of the attunements of freedom and love, Dasein and Dasein-with express themselves through the mode of dissimulation and of deviance from themselves, which levels and gregarizes the being-with-one-another of Dasein and Dasein-with. Because in these modes, Dasein and Dasein-with exempt themselves from the responsibility of being themselves and throw upon the other the necessity of taking on the freedom of being.

To embrace a "thing" or a "person" in their essence means to love them, to favor them. Thought in a more original way such favoring means the bes- 
towal of their essence as a gift. Such favoring [Mögen] is the essence of enabling [Vermögen], which not only can achieve this or that but also can let something essentially unfold in its provenance, that is, let it be (Heidegger, 1998: p. 241).

To be bestowed with a Dasein does not mean to be in its place, to assume its cares, nor does it means to save this Dasein from itself. Rather, it means a gift of being, that is, a gratuitous unfolding of the freedom of possibilities of being and a generosity in abandoning oneself to the unconcealment of the entity and in the granting of its provenance of being other than oneself. This means to commit jointly so that each one may be free for being that which authentically is itself. The commitment of Dasein to understand and admit the possibility-of-being that it is and understanding and freeing Dasein-with to assume the possibility-of-being that which it is, expresses the character of Dasein's disclosedness to the other as letting-be Dasein-with. In this type of commitment the inauthentic modes of the attunement of love become suspended, held in abeyance. Better, in this commitment the control over the mode of being of Dasein-with is suspended, as is the demand that the Dasein-with be this or that mode. Also suspended is the bargaining or trading of possibilities of being. With this suspension we have the bestowing of Dasein in the mode of free commitment to allow Dasein-with to be that which it is. That is to say we have the authentic mode of attunement of love. We consider that this mode of attunement that cares for, understands, and frees Dasein-with to be itself is necessary and fundamental to the free being-one-another and reciprocity of Dasein and Dasein-with. In this perspective, we think that, in Heidegger, the attunement of love demands co-originarity and copertinence with the attunement of freedom. However, freedom as letting-be Dasein that which it is itself, "is nothing else than the knowledge which of necessity resonates in his [all] love." (Heidegger, 1991: p. 207).

In order to better study this theme in the future, we intend to answer the question: why do we love? We think that we love because, as Dasein, we are constituted by the existential, which structures us as disclosedness to being, to the other, and to the world. Our intention will be to indicate the concepts of existential analytic that, for us, are fundamental to ground love as Dasein's way of being, i.e., as an existential mode of Dasein as existence and being-in-the-world. We intend to show why we can accept love as an existential mode, and discuss how we can say that love comes from the existential of being-in, of being-with and of the character of for-the-sake-of (Umwillen).

\section{References}

Agamben, G. (2008). The Passion of Facticity. In F. Raffoul, \& E. S. Nelson (Eds.), Rethinking Facticity (pp. 89-112). Albany: State University of New York Press.

Dahlstrom, D. O. (2013). The Heidegger Dictionary. London and New York: Bloomsbury. Dastur, F. (2008). Binswanger lecteur de Être et temps. Amour, nostrité et souci. In P. 
Cabestan, \& F. Dastur (Eds.), Lectures d'Être et temps de Martin Heidegger. Quatre-vingts ans après (pp. 101-120). Argenteuil: Le Cercle Herméneutique.

Figal, G. (1988). Martin Heidegger Phänomenologie der Freiheit. Frankfurt: Athenäum.

Greisch, J. (1994). Ontologie et temporalité esquisse d'une interpretation intégrale de Sein und Zeit (pp. 33-48). Paris: PUF.

Heidegger, M. (1951). Hölderlin und das Wesen der Dichtung. In Erläuterungen zu Hölderlins Dichtung. Frankfurt: Vittorio Klostermann.

Heidegger, M. (1991). Nietzsche I. Translated by David Farrel Krell, San Francisco: Harper.

Heidegger, M. (1995). The Fundamental Concepts of Metaphysics: World, Finitude, Solitude. Translated by William McNeill and Nicholas Walker, Bloomington and Indianapolis: Indiana University Press.

Heidegger, M. (1998). Plato's Doctrine of Truth. In W. McNeill (Ed.), Pathmarks (pp. 155-182). Translated by Thomas Sheehan, Cambridge: Cambridge University Press.

Heidegger, M. (1998). On the Essence of Truth. In W. McNeill (Ed.), Pathmarks (pp 136-154). Translated by John Sallis, Cambridge: Cambridge University Press. https://doi.org/10.1017/CBO9780511812637

Heidegger, M. (1998). Letter on "Humanism". In W. McNeill (Ed.), Pathmarks (pp. 239-276). Translated by Frank A. Capuzzi, Cambridge: Cambridge University Press. https://doi.org/10.1017/CBO9780511812637

Heidegger, M. (2001). Zollikon Seminars. Translated by Franz Mayr and Richard Askay, Evanston, IL: Northwestern University Press.

Heidegger, M. (2008). Being and Time. Translated by John Macquarrie and Edward Robinson, New York, NY: Harper Perennial.

Heidegger, M. (2010). Being and Time. Translated by Joan Stambaugh, Revised by Dennis J. Schmidt, Albany, NY: State University of New York Press.

King, M. (2001). A Guide to Heidegger's Being and Time. New York, NY: State University of New York.

Safranski, R. (2006). Heidegger e el comenzar. Translated by Joaquim Chamorro, Madrid: Ediciones Pensamiento. 